\section{B A Institute of \\ YK Business Administration \\ 六下 \\ Karachi \\ Leadership and Ideas for Tomorrow}

\section{Business Review}

Volume 3 Issue 1 January-June 2008

$1-1-2008$

\title{
Economic reforms and total factor productivity growth in Pakistan: An empirical analysis
}

\author{
Muhammad Sabir \\ Social Policy and Development Centre (SPDC) Karachi, Pakistan \\ Qazi Masood Ahmed \\ Institute of Business Administration, Karachi, Pakistan
}

Follow this and additional works at: https://ir.iba.edu.pk/businessreview

Part of the Growth and Development Commons

\section{(c) (1)}

This work is licensed under a Creative Commons Attribution 4.0 International License.

\section{Recommended Citation}

Sabir, M., \& Ahmed, Q. M. (2008). Economic reforms and total factor productivity growth in Pakistan: An empirical analysis. Business Review, 3(1), 53-68. Retrieved from https://doi.org/10.54784/

1990-6587.1132

This article is brought to you by iRepository for open access under the Creative Commons Attribution 4.0 License and is available at https://ir.iba.edu.pk/businessreview/vol3/iss1/6. For more information, please contact irepository@iba.edu.pk. 


\title{
ARTICLE
}

\section{Economic Reforms and Total Factor Productivity Growth in Pakistan: An Empirical Analysis}

\author{
Muhammad Sabir \\ Social Policy and Development Centre (SPDC) Karachi, Pakistan \\ Qazi Masood Ahmed \\ Institute of Business Administration Karachi, Pakistan
}

\section{INTRODUCTION}

$\mathrm{P}^{\mathrm{a}}$ akistan has been following an agenda of economic reform encompassing a broad range of structural adjustment policies (SAP) since 1987-88. These policies have an adverse impact on the pace of economic growth and are a cause of higher poverty and inequality in the country (see Bengali and Ahmed (2002), Kemal (2003)). The impact of structural adjustment programme on total factor productivity is generally ignored. While the popular belief is that SAP results in low growth in factor inputs, which causes the low economic growth. This paper argues that decline in the growth of total factor productivity is the main cause of low economic growth. The present paper is the first attempt in Pakistan to establish the link between structural adjustment policies and total factor productivity and to quantify the impact of these policies on total factor productivity over the time.

This paper compares the average growth rates in GDP, factor inputs and total factor productivity during pre-reform period 1972-73 to 1987-88 and the reform period 1987-88 to 2001-02 and summarizes the historical patterns. Particular attention is given to assessing the impact of structural adjustment policies on total productivity growth directly and indirectly through other determinants of total factor productivity growth, such as human capital etc.

The paper is organized in the following six sections: after the introduction, section 2 presents a brief review of recent research on the elements of total factor productivity and its determinants. Section 3 examines alternative approaches to measure total factor productivity. Section 4 highlights the sources of growth in the Pakistan's economy. Section 5 summarizes the causes of slow growth in total factor productivity based on econometric analysis. Section 6 offers concluding remarks.

\section{REVIEW OF LITERATURE}

In recent years, a growing body of research highlights the role of economic reforms in the growth of total factor productivity (TFP). Generally, the term economic reform 
refers to macroeconomic stabilization and structural adjustment policies which includes trade liberalization, and contractionary fiscal and monetary policies. It is argued that trade liberalization leads to higher competition, which is ultimately met through higher total factor productivity growth. Similarly, reduction in government subsidies, privatization and deregulation also leads to higher competition and has the same affect. However, there are many controversies about the direct and indirect linkages between structural adjustment policies. This section presents a brief review about the impact of structural adjustment programme on total factor productivity growth.

Edwards (1997) analyzes the robustness of the relationship between openness and TFP growth by using a comparative data of 93 countries and nine alternative indices of trade policies. He finds positive relationship between openness and TFP growth. Similarly Weihold and Rauch (1997) tested the hypothesis that openness promotes specialization, which translated into higher productivity growth. Based on the dynamic panel analysis for the manufacturing sector in 39 less developed countries, their results show that the index of specialization is positively and significantly correlated with manufacturing productivity growth.

Bjurek and Durevall (1998) analyze the contribution of the structural adjustment program to the growth of total factor productivity in Zimbabwe's manufacturing sector. To evaluate the change in growth of TFP, the authors first estimate indices of total factor productivity for 31 manufacturing sub-sectors for the period 1980-1995. Then they use panel data methods to test for the effects of trade reform and other variables related to SAP. The overall impression is that there was no growth in total factor productivity on average during the whole period of SAP, accept, during the last two years of reform, (1994-1995), when most sub-sectors experienced increases in total factor productivity.

Similarly, Isgut, Tello and Veiderpass (1999) measure and analyze total factor productivity and technical efficiency in a large sample of Nicaraguan manufacturing firms. Their analysis indicates that whereas structural reforms may be necessary conditions for the development of developing economies, their expected positive effects on sources of growth such as total factor productivity and technical efficiency could be so slow that it may be necessary to develop policy instruments for spurring economic growth in the short run.

Wobst (2001) analyzes the impact of stabilization and structural adjustment policies on Tanzania's macroeconomic performance, inter-sectoral shifts, and household welfare applying a CGE model based on a 1992 SAM. The results indicate that structural adjustment measures have an adverse effect on the overall performance and the sectoral structure of Tanzania's economy. Bautista et al (2002) investigates the income and equity effects of macroeconomic policy reforms in Zimbabwe relating to the Economic Structural Adjustment Program. Their CGE model simulations show that trade policy reform alone increases GDP, agricultural 
production, and aggregate disposable household income. In addition, foreign trade expands markedly (by about a quarter of the base year value). These aggregate effects are even larger when trade liberalization is accompanied.

The above review of literature reveals three massages: (i) government effort to reduce budget deficit through reduction in input subsidies affected the producer and ultimately TFP, (ii) trade liberalization measures resulted in higher competition and specialization, which in turns also affected TFP, and finally, (iii) government and private expenditures on research and development and infrastructure development increase the level of growth of TFP.

\section{METHODOLOGY}

There are several approaches available to measure productivity. At the most basic level, productivity change is often approximated by changes in labour productivity (output per worker or per hour worked) because the requisite information is usually readily available. However, relying on labour productivity measures can produce misleading results as other inputs such as capital may be being substituted for labour. If this is happening, observed labour productivity will be increasing rapidly but when all inputs are taken into account, overall productivity will be increasing far less rapidly and, in the extreme case, may even be declining. To overcome this deficiency, it is necessary to look at the quantity of all outputs produced relative to the quantity of all inputs used. This comprehensive productivity measure is known as total factor productivity (TFP) and should ideally include not just labour and capital inputs but also land, natural resource, inventory and all other inputs. Most productivity studies tend to concentrate on labour and capital inputs and some analysts recognize the incompleteness of their input coverage by referring to the resulting measures as 'multifactor' rather than 'total factor' productivity measures.

There are two broad approaches used to measure total factor productivity: Growth Accounting Approach and Index Number Approach.

\subsection{The Solow Growth Accounting Approach}

A much-cited 1957 paper by Solow provides a useful frame of reference for the main empirical approaches to measuring TFP known as growth accounting approach. With this approach, TFP is computed as a residual: the contributions of specified input factors to output growth is calculated and then subtracted from the total growth of output. The resulting residual difference is referred to as 'the Solow residual'.

Solow (1957) represents the production function as:

$$
Q=F(K, L ; t) \text {. }
$$

In this specification, $Q$ is an output quantity aggregate (usually taken to be real gross domestic product in the national accounting framework), $K$ and $L$ are aggregate 
measures for the capital and labour inputs to the production process, and $t$ denotes time. The variable $t$ appears in $F$ 'to allow for technical change.' If technical change is neutral, the shifts in production leave all marginal rates of substitution unchanged, and the production function $F$ in (1) can be written as:

$$
Q=A(t) f(K, L) \text {. }
$$

The multiplicative factor $A(t)$ in (2) represents the cumulative effects of shifts over time after controlling for the growth of $K$ and L. If we differentiate equation (2) totally with respect to time and then divide by $\mathrm{Q}$ we obtain

$$
\frac{\Delta \mathrm{Q}}{\mathrm{Q}}=\frac{\Delta A}{A}+w_{K} \frac{\Delta K}{K}+w_{L} \frac{\Delta L}{L},
$$

where

$$
w_{K}=A \frac{\partial f}{\partial K} \frac{K}{Q} \quad \text { and } w_{L}=A \frac{\partial f}{\partial L} \frac{L}{Q}
$$

Rearranging (3) leads to the following expression for productivity change:

$$
\frac{\Delta A}{A}=\frac{\Delta Q}{Q}-w_{K} \frac{\Delta K}{K}-w_{L} \frac{\Delta L}{L}
$$

In other words, productivity change is equal to the rate of output growth less the rates of growth in capital and labour inputs weighted by their respective GDP shares.

\subsection{THE INDEX NUMBER APPROACH}

A productivity index is generally defined as the ratio of an index of output growth divided by an index of input growth, where output refers to the total quantities of all outputs produced by the production sector and the inputs are the total quantities of all inputs utilized by the same production sector over two accounting periods.

Most economies have a diverse range of outputs (agricultural products, manufactures, and services) and an equally diverse range of inputs (labour, capital, land and natural resources). Calculating TFP requires a means of adding together these diverse output and input quantities into measures of total output and total input quantity. The TFP index can be written as:

$$
\mathrm{TFP}=\mathrm{Q}_{\mathrm{t}} / \mathrm{I}_{\mathrm{t}}
$$

\section{SOURCES OF GROWTH IN PAKISTAN'S ECONOMY}

It emerged from the review of literature that macroeconomic reforms have dissimilar impact on different sectors of the economy. For, instance openness policies largely affect the manufacturing sector. Taking this into account, this study presents a sector-wise impact analysis of macroeconomic reforms on overall growth performance of the economy, growth in factor inputs and growth in TFP. As a first step four production functions are estimated for the agriculture, manufacturing and 
services sectors, and for the overall GDP. In the second step, growth in factor inputs and overall economy is calculated.

\subsection{Estimates of Production Function}

Table 1 presents the results of the estimates of Cobb Douglas production functions for each sector and the overall economy. All variables except the dummy variables and physical stock of economic infrastructure are taking in the logarithmic form.

The sum of coefficients of labour force and physical capital in manufacturing and services sectors is one and, in the rest of the cases, the sum of the coefficients of cropped area, labour and physical capital stock is one. This indicates that the underlying production function is constant return to scale and neutral in technical progress. This also implies that the overall growth rate of factor inputs is the weighted sum of the growth rate of inputs of land, labour and capital, with the weights adding up to unity.

\subsection{GROWTH IN FACTORS INPUTS}

Table-2 presents the sector-wise growth in three standard factor inputs (land, labour, and capital) during the pre-reform (1972-73 to 1987-88) and during the macroeconomic reform (1987-88 to 2001-02) period. It clearly emerges from the constant growth that there is no impact of reform on cropped area. However, there is substantial change in the pattern of growth of capital accumulation, which experiences the highest growth (12 percent) in the agriculture sector, a relatively slower growth of 6 percent in the services sector and remains stagnant in the manufacturing sector during the first period of analysis. This trend reverts in the second period of the analysis with highest capital accumulation growth in the services sector and lowest in the agriculture sector. Interestingly, capital accumulation in the manufacturing sector picks the pace and shows relatively higher growth (4 percent) in the second period of analysis. Overall, the economy experiences relatively high growth in capital accumulation in the second period of analysis.

In contrast, growth in employed labour force declines in all sectors of the economy during the macroeconomic reform period. However, the major decline in growth of employed labour force is reflected in the manufacturing sector, which shows almost 40 percent decline in annual average employed labour force during the macroeconomic reform period.

Different types of inputs simply cannot be added, e.g. it is not meaningful to add the number of employees to the cropped area. Therefore, based on neoclassical growth theory estimated production functions for each sector are used to obtained the respective weights of input, which are then multiplied with the index of capital, labour and land and finally add to get the Index of Factor Inputs. 
Based on the estimates of sector-wise growth rates of factor inputs presented in Table - 2. It can be concluded that, except for the agriculture sector, growth in factor inputs is relatively higher during the period of reform. The increase in growth of factor inputs is noticeable in the manufacturing sector, which experiences almost one percentage point increase in annual average growth of factor inputs. However, agriculture shows a decline in growth of factor inputs during the macroeconomic reform period.

\subsection{GROWTH PERFORMANCE OF THE ECONOMY}

Table-3 presents the sector-wise economic growth rates during the pre-reform period (972-73 to 1987-88) and during the reform period (1987-88 to 2001-02). Prior to macroeconomic reform, annual average growth rates in agriculture, manufacturing and services sectors were 3.5, 7.4 and 6.9 percent respectively, which change substantially in the reform period to 3.9, 4.3 and 4.5 percent respectively. As a result, growth in overall economy slows down from 5.9 percent to 4.3 percent, and the major contributors to the decline in growth are the manufacturing and services sectors.

It is important to notice that the pattern of growth in outputs is entirely different than the pattern of growth in inputs. For instance, in the agriculture sector, the growth in input is high prior to reform; however, growth in output is high during the reform period. Similarly, the high growth in factor inputs is not translated into output growth in the manufacturing and services sectors. As a result, despite the growth in factor inputs in the economy, output growth declines from 5.9 percent to 4.3 percent during the period. This finding indicates that the role of total factor productivity play a substantial part to explaining the pattern of growth in the economy.

\subsection{DECOMPOSITION OF ECONOMIC GROWTH}

It is important to decompose growth in the economy into growth in factor inputs and growth in total factor productivity (TFP) to understand the nature economic growth. In the first step, growth rates of TFP are computed, which are simply the difference of sector wise growth rates of the economy and growth rates of factor inputs. Table-3 also presents the results of this computation during the respective periods and for each sector of the economy.

TFP growth shows a mixed pattern: it is highest in manufacturing sector prior to reform and lowest in the services sector during reform. On average, almost half of the growth in the economy prior to reform is the outcome of growth in TFP and the remaining half is contributed by growth in factor inputs. However, during the reform period, annual average growth in TFP has declines from 2.8 percent to 0.7 percent. As a result, the contribution of TFP in overall economic growth also declines from 
48 percent to just 16 percent, which is the main cause of low economic growth during the reform period.

\section{IMPACT OF MACROECONOMIC REFORM ON TFP GROWTH}

Pakistan has adopted an agenda of macroeconomic reforms since 1987-88, which is basically a set of structural adjustment policies. The Structural Adjustment Programme required the slashing of the budget deficit and the current account deficit as well as a range of sectoral reforms. The liberalization of the financial sector in 1991, and the wholesale privatization of state owned industrial enterprises in 1992. However, these policies affect different sectors of the economy with different magnitudes, as a consequence agriculture, manufacturing and services sectors experinace dissimilar impact of reform. Therefore, the impact of macroeconomic reform on each sector of the economy is seprately estimated. This estimation process is also divided into two steps, first we specify a number of common explanatory varaible, which can be used to estbalish the link between economic reforms and TFP. Second based on the estimates of OLS equation the realtive contribution of each sector is computed.

Table -4 presents the result of OLS equations with dependent variables are the Index of total factor productivity sector-wise and overall economy. There are many alternative variables are used in estimation which link the structula adjustement and TFP and the best fit model are presented and used for further analysis. In above model all variables are significant without serial correlation and more than 93 percent variation.

\subsection{IMPACT OF REFORM ON TFP GROWTH: AGRICULTURE SECTOR}

Agriculture is the least affected sector of the economy. Generally, three sets of macroeconomic policies affect agriculture sector in Paksitan: (i) the policies related to factor inputs subsidies, (ii) decsions related to support prices for major crops, and finally (iii) tarde liberalization policies. Even though, it is difficult to trace the direct links of these policies on agriclture sector, an attempt is made to establish direct and indirect links and their impact on TFP growth.

The major input indirect subsidy is provided to the agriculture sector through subsidized rates of gas tariff to fertilizer sector. However, this input subsidy as a result of macroeconomic reform has been gardually abolished in 1995-96. In contrast to input subsidies culture of support prices still prevails in the economy and even shows higher increase in support prices during reform period specially in sugarcane and wheat, which jointly consumed the large part of government current subsidies. Finally, trade liberalization through reduction in tariff rate reduces the cost of imported pesticide and fertilizer and through devaluation provide insintaive to export 
cotton and cotton based finish goods and ultimately positively affect the cotton grower.

There are several alternative models of determinant of TFP in agriculture sector have estimated to compute the impact of macroeconomic reforms. Human capital index, index of fertilizer use per hectre and index of cotton yield are included in final model as determinants of TFP in agriculture. The choice of variabbles based on the following rationales: human capital index is included to capture the impact of increase in labour quality based on education and experience, index of fertilizer use per hectre is used as proxy to capture the impact of currenrt and development subsidies to agriculture sector and finally, index of cotton is incorporated to capture the impact of trade liberalization on TFP.

Table-5 presents the result of variance decomposition based on the regression to quantify the relative contribution of different factors. The most important factor in the growth in TFP is human capital. Prior to reform human capital formation contribute significantly and the main engine of growth in TFP. However, it is emerge that during the reform period growth of human capital is decline in the country. This is largely the outcome of reduction in social sector expenditures in real terms.

It emerges that food and fertilizer subsidies play an important role in both prior to reform and during reform periods in the growth of TFP in agriculture. Prior to reform government spend big amounts on fertilizer subsidy, which increase the consumption and as a result TFP decline. On the contrary during reform period government subsequently abolish fertilizer subsidy and as a result of high prize of fertilizer efficiently, which leads to increase in TFP. In contrast to fertilizer subsidy, ongoing fiscal does not affect food subsidies and these food subsidies provide incentive to farmers through support price, which in turn try to increase production and ultimately a cause of TFP growth. However, the only variable to capture benefit of trade liberalization is cotton yield does not work according to expectation and can not contribute positively during reform period.

\subsection{IMPACT OF REFORM ON TFP GROWTH: MANUFACTURING SECTOR}

The manufacturing sector is one of the two legs on which the commodity-producing edifice of the economy stands. Prior to macroeconomic reform, this sector enjoyed a substantial rate of effective protection through high import duties and low domestic taxes. However, as a result of macroeconomic reform the maximum tariff rate declined from 150 percent in 1988 to 35 percent in 2001-02- about one-fifth of the 1988, similarly, the effective import duty rate decline from 38.4 percent to 13 per cent in 2001-02. Devaluation Pakistani currency is another important policy of the trade liberalization reform that affects the growth of TFP in manufacturing sectors. 
Finally, the governments strategy of reduction in budget deficit through reduction in development expenditure is also affect the TFP growth.

Table-6 presents the estimates of contribution of different factors to growth of TFP in manufacturing sector in both prior to reform and during the reform periods. Contrary to general believe trade liberalization through manufactured export account lesser in TFP growth during reform period as compare to pre reform period. Similarly, share of new investment in capital accumulation negatively contribute in both periods. However, the major cause of low growth of TFP in reduction in development expenditures, which experience negative contribution in TFP growth during reform period.

\subsection{IMPACT OF REFORM ON TFP GROWTH: SERVICES SECTOR}

Services sector in Pakistan accounted for about half of GDP, with varied proportion between early 1970s and 2000s. In early 1970s almost 45 percent of GDP came from services sectors, which increases to 57 percent of GDP in 2002-03. Despite the growing contribution of services sector in GDP, the country has a persistent trade deficit in services sector. Moreover, the disaggregated pattern shows that during the reform period growth in TFP declined from 1.6 percent to the negative 0.9 percent. This is largely the outcome of decline in development expenditure and human capital (see Table 7), which is inline with the findings of other sectors.

\subsection{IMPACT OF REFORM ON TFP GROWTH: OVERALL ECONOMY}

It is important to highlight the impact of economic reform on TFP growth of the overall economy. The empirical result indicates that except new investment all other determinant of TFP growth declined during the reform period. In other words, the productivity of new investment increses in the reform period, however, contribution of human capital, remittances, development expenditures and cotton exports has declined during the reform period. These declines are the outcome of economic reforms and stablization policies.

\section{CONCLUSION}

The role of economic reform on growth is an area of great debate and empirical investigation. This paper provides empirical evidences that the economic reform policies of Government of Pakistan are the major contributor in the change of total factor productivity. In those periods when the fiscal policy is appropriate for growth and allows increase in expenditure on development and social services, it always has positive impact on total factor productivity. Similarly in those period when the total factor productivity was low it can be explained in terms of reduction in government expenditures on social and development services. 
TABLE - 1 SECTOR-WISE ESTIMATES OF PRODUCTION FUNCTION

\begin{tabular}{|c|c|c|c|c|}
\hline & \multicolumn{4}{|c|}{ Dependent Variables: } \\
\hline & $\begin{array}{l}\text { Real Value } \\
\text { Added in } \\
\text { Agriculture } \\
\text { Sector }\end{array}$ & \begin{tabular}{|c|} 
Real Value \\
Added in \\
Manufacturing \\
Sector
\end{tabular} & $\begin{array}{l}\text { Real Value } \\
\text { Added in } \\
\text { Services } \\
\text { Sectors }\end{array}$ & Real GDP \\
\hline \multirow{2}{*}{ Constant } & 4.112 & -13.001 & -4.246 & 0.438 \\
\hline & (3.54) & $(-48.31)$ & $(-4.71)$ & $(0.49)$ \\
\hline \multirow{2}{*}{$\begin{array}{l}\text { Sector-wise Real } \\
\text { Stock of Physical } \\
\text { Capital }\end{array}$} & 0.048 & 0.424 & 0.599 & 0.438 \\
\hline & (14.10) & $(14.10)$ & (6.59) & (19.91) \\
\hline $\begin{array}{l}\text { Sector-Wise } \\
\text { labour Force }\end{array}$ & 0.250 & 0.576 & 0.401 & 0.347 \\
\hline \multirow{2}{*}{ Cropped Area } & 0.702 & & & 0.215 \\
\hline & $(8.12)$ & & & $(6.60)$ \\
\hline $\begin{array}{l}\text { Sector-wise Stock } \\
\text { of Physical }\end{array}$ & 0.002 & 0.831 & 0.238 & 0.452 \\
\hline Economic & (24.87) & (50.21) & $(6.01)$ & (14.35) \\
\hline \multirow{2}{*}{ Dummy Variables } & 0.063 & -0.154 & -0.207 & -0.033 \\
\hline & (6.24) & $(-8.03)$ & $(-6.92)$ & $(-5.24)$ \\
\hline Adjusted R ${ }^{2}$ & 0.997 & 0.995 & 0.996 & 0.999 \\
\hline Durbin-Watson & 2.053 & 1.842 & 1.527 & 1.976 \\
\hline
\end{tabular}

t-statistics in parentheses.

TABLE - 2

GROWTH IN FACTOR INPUTS

Annual Average Growth Rate

\begin{tabular}{|l|c|r|r|r|}
\hline \multicolumn{1}{|c|}{ Period } & All Factor Inputs & Capital & Labour & \multicolumn{2}{c|}{ Land } \\
\hline \hline Factor Inputs Growth in Agriculture Sector & \multicolumn{3}{|c}{} \\
1972-73 to 1987-88 & $\mathbf{2 . 0}$ & 12.0 & 2.0 & 0.5 \\
$1987-88$ to 2001-02 & $\mathbf{1 . 2}$ & 2.5 & 1.8 & 0.5 \\
\hline $\mathbf{1 9 7 2 - 7 3}$ to 2001-02 & $\mathbf{1 . 6}$ & $\mathbf{7 . 4}$ & $\mathbf{1 . 9}$ & $\mathbf{0 . 5}$ \\
\hline
\end{tabular}

(Remaining part on the following page) 


\begin{tabular}{|c|c|c|c|c|}
\hline \multicolumn{5}{|c|}{ Factor Inputs Growth in Manufacturing Sector } \\
\hline $1972-73$ to $1987-88$ & 1.5 & 0.1 & 2.5 & - \\
\hline $1987-88$ to $2001-02$ & 2.4 & 4.0 & 1.5 & - \\
\hline 1972-73 to 2001-02 & 1.9 & 2.0 & 2.0 & - \\
\hline \multicolumn{5}{|c|}{ Factor Inputs Growth in Services Sector } \\
\hline $1972-73$ to $1987-88$ & 5.2 & 6.1 & 3.9 & - \\
\hline $1987-88$ to $2001-02$ & 5.5 & 6.4 & 3.0 & - \\
\hline 1972-73 to 2001-02 & 5.3 & 6.3 & 3.5 & - \\
\hline \multicolumn{5}{|c|}{ Factor Inputs Growth in Overall Economy } \\
\hline $1972-73$ to $1987-88$ & 3.1 & 4.4 & 2.6 & 0.5 \\
\hline $1987-88$ to $2001-02$ & 3.6 & 5.0 & 2.1 & 0.5 \\
\hline $1972-73$ to $2001-02$ & 3.3 & 4.7 & 2.4 & 0.5 \\
\hline
\end{tabular}

\section{TABLE - 3 \\ SECTOR-WISE SOURCES OF GROWTH OF PAKISTAN'S ECONOMY PRE AND DURING MACROECONOMIC REFORM PERIODS}

Average Annual Growth Rate

\begin{tabular}{|c|c|c|c|c|}
\hline Period & Agriculture & Manufacturing & Services & GDP \\
\hline \multicolumn{5}{|c|}{ Growth Performance of the Economy } \\
\hline $1972-73$ to $1987-88$ & 3.5 & 7.4 & 6.9 & 5.9 \\
\hline $1987-88$ to $2001-02$ & 3.9 & 4.3 & 4.5 & 4.3 \\
\hline 1972-73 to 2001-02 & 3.7 & 5.9 & 5.7 & 5.1 \\
\hline \multicolumn{5}{|c|}{ Growth in Factor Inputs } \\
\hline $1972-73$ to $1987-88$ & 2.0 & 1.5 & 5.2 & 3.1 \\
\hline $1987-88$ to $2001-02$ & 1.2 & 2.4 & 5.5 & 3.6 \\
\hline 1972-73 to 2001-02 & 1.6 & 1.9 & 5.3 & 3.3 \\
\hline \multicolumn{5}{|l|}{ Growth in TFP } \\
\hline $1972-73$ to $1987-88$ & 1.5 & 5.9 & 1.7 & 2.8 \\
\hline $1987-88$ to $2001-02$ & 2.6 & 1.9 & -1.0 & 0.7 \\
\hline 1972-73 to 2001-02 & 2.0 & 4.0 & 0.4 & 1.8 \\
\hline \multicolumn{5}{|c|}{ Contribution of TFP in Economic Growth (\%) } \\
\hline $1972-73$ to $1987-88$ & 42.3 & 79.3 & 24.3 & 48.2 \\
\hline $1987-88$ to $2001-02$ & 68.0 & 45.0 & -22.5 & 16.1 \\
\hline 1972-73 to 2001-02 & 55.3 & 67.2 & 6.7 & 35.3 \\
\hline
\end{tabular}

Source: Pakistan Economic Survey Various Issues \& Authors' Estimate 
TABLE - 4

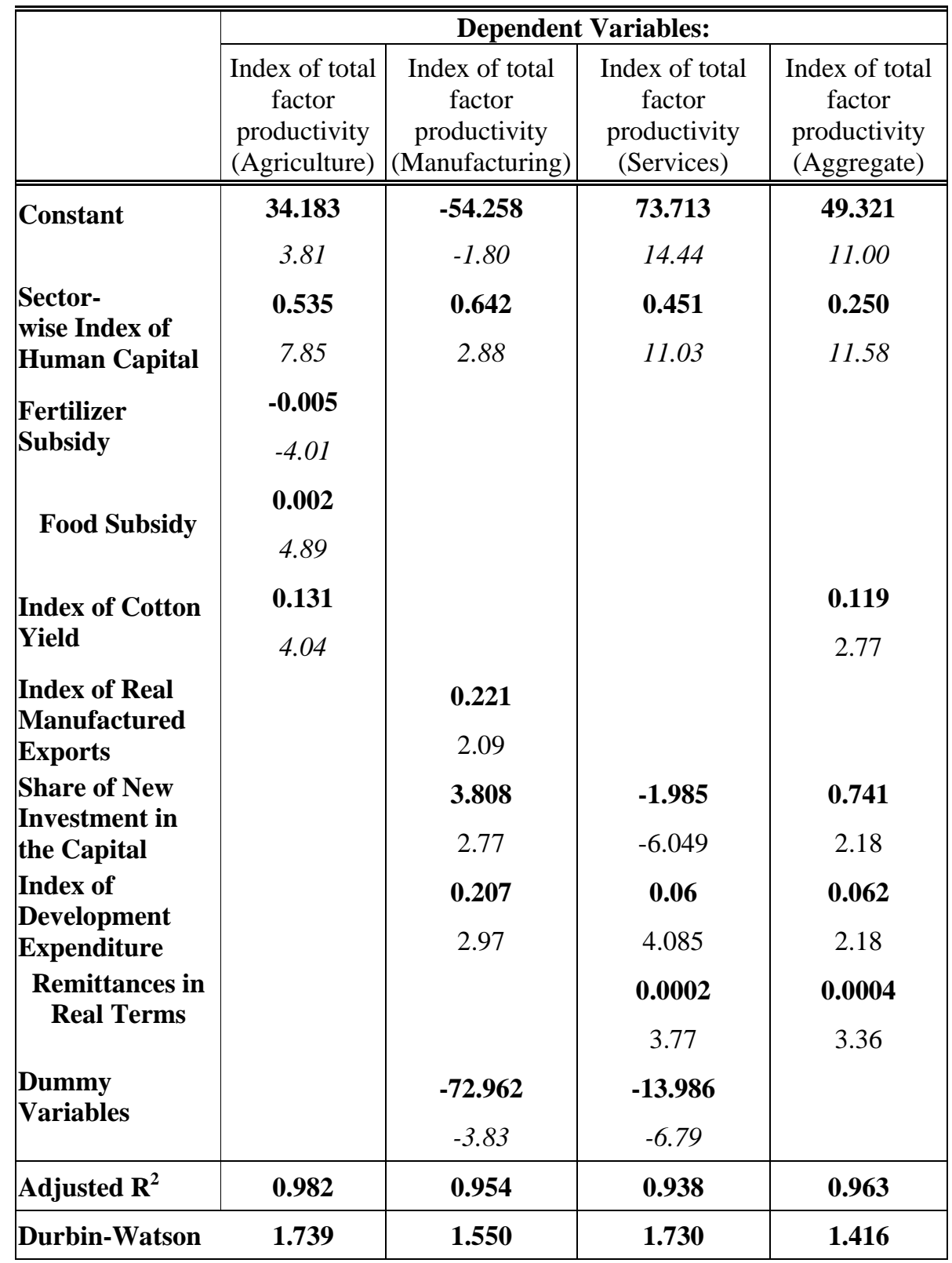

t-statistics in italics. 
TABLE - 5

IMPACT OF REFORM ON GROWTH OF TFP AGRICULTURE

Annual Average Growth Rate

\begin{tabular}{|l|c|c|c|}
\hline \multicolumn{1}{|c|}{ Factors } & 1972-73 to 2001-02 & $\mathbf{1 9 7 2 - 7 3}$ to 1987-88 & 1987-88 to 2001-02 \\
\hline \hline & & & \\
Human Capital & $\mathbf{3 . 9}$ & 6.2 & 1.6 \\
Fertilizer Subsidy & $\mathbf{- 2 . 1}$ & -4.8 & 0.6 \\
Food Subsidy & $\mathbf{0 . 1}$ & -0.4 & 0.5 \\
Cotton Yield & $\mathbf{0 . 8}$ & 1.6 & -0.1 \\
Unexplained & $\mathbf{0 . 1}$ & 0.2 & -0.1 \\
Growth in TFP & $\mathbf{2 . 0}$ & $\mathbf{1 . 4}$ & $\mathbf{2 . 6}$ \\
\hline
\end{tabular}

TABLE - 6

Impact of Reform on Growth of TFP Manufacturing Annual Average Growth Rate

\begin{tabular}{|c|c|c|c|}
\hline Factors & 1972-73 to 2001-02 & $1972-73$ to $1987-88$ & 1987-88 to 2001-02 \\
\hline $\begin{array}{l}\text { Human Capital } \\
\text { Manufactured }\end{array}$ & 2.3 & 2.3 & 1.5 \\
\hline Exports & 1.5 & 1.6 & 0.9 \\
\hline $\begin{array}{l}\text { Vintage of Capital } \\
\text { Development }\end{array}$ & -0.2 & -0.3 & -0.1 \\
\hline Expenditures & 0.6 & 2.8 & -0.3 \\
\hline Unexplained & -0.2 & -0.4 & 0.0 \\
\hline Growth in TFP & 4.0 & 5.9 & 2.0 \\
\hline
\end{tabular}

TABLE - 7

Impact of Reform on Growth of TFP Services

Annual Average Growth Rate

\begin{tabular}{|l|c|c|c|}
\hline \multicolumn{1}{|c|}{ Factors } & $\mathbf{1 9 7 2 - 7 3}$ to 2001-02 & $\mathbf{1 9 7 2 - 7 3}$ to 1987-88 & 1987-88 to 2001-02 \\
\hline \hline & $\mathbf{0 . 7}$ & 0.9 & 0.6 \\
Human Capital & $\mathbf{0 . 2}$ & 0.3 & 0.0 \\
Remittances & $\mathbf{- 1 . 0}$ & -1.4 & -0.7 \\
Vintage of Capital & & & \\
Development & $\mathbf{0 . 9}$ & 2.2 & -0.5 \\
Expenditures & $\mathbf{0 . 3}$ & -0.5 & -0.2 \\
Unexplained & $\mathbf{0 . 4}$ & $\mathbf{1 . 6}$ & $\mathbf{- 0 . 9}$ \\
Growth in TFP & & & \\
\hline
\end{tabular}


TABLE - 8

Impact of Reform on Growth of TFP IN the Economy Annual Average Growth Rate

\begin{tabular}{|l|r|r|r|}
\hline \multicolumn{1}{|c|}{ Annual Average Growth Rate } \\
\hline \hline \multicolumn{1}{|c|}{ Factors } & $\mathbf{1 9 7 2 - 7 3}$ to 2001-02 & $\mathbf{1 9 7 2 - 7 3}$ to 1987-88 & $\mathbf{1 9 8 7 - 8 8}$ to 2001-02 \\
Human Capital & & & \\
Remittances & $\mathbf{0 . 9 3}$ & 1.10 & 0.76 \\
Vintage of Capital & $\mathbf{0 . 2 6}$ & 0.47 & 0.03 \\
Development & $\mathbf{0 . 0 4}$ & -0.06 & -0.03 \\
Expenditures & & & -0.09 \\
Cotton Yield & $\mathbf{0 . 3 3}$ & 0.73 & 0.01 \\
Unexplained & $\mathbf{0 . 2 6}$ & 0.50 & 0.00 \\
Growth in TFP & $\mathbf{0 . 0 1}$ & 0.02 & $\mathbf{0 . 6 8}$ \\
\hline
\end{tabular}

\section{REFERENCES}

Anthony Enisan Akinlo (2005) Impact of Macroeconomic Factors on Total Factor Productivity in Sub-Saharan African Countries” Research Paper No. 39 UN-WIDER

Barro, R. J. (1990). 'Government spending in a simple model of endogenous growth’. Journal of Political Economy 98(5 part 2): S103-S125.

Barro, R. J. and Lee, J. (1994). 'International comparisons of educational attainments'. Journal of Monetary Economics 32: 363-94.

Barro, R. J. and Sala-I-Martin, X. (1995). Economic Growth. New York: McGraw-Hill.

Coe, D. T. and Helpman, E. (1995). 'International R\&D spillovers'. European Economic Review 39: 859-87.

Cororation, C. B. (2004). 'National Report: Philippines', in Measuring Total Factor Productivity: Survey Report. Tokyo: Asian Productivity Organization.

Edwards, S. (1998). 'Openness, productivity and growth: What do we really know?' Economic Journal 108: 383-98.

Englander, S. and Gurney, A. (1994). 'Medium-term determinants of OECD productivity’. OECD Economic Studies 22: 49-109.

Goldar, B. N. and Kumari, A. (2002). 'Import liberalization and productivity growth in India industries in the 1990s'. Working Paper E/219/2002. Delhi: Institute of Economic Growth. 
Griliches, Z. (1980). 'Returns to research and development expenditures in the private sector', in J. Kendrick and B. Vaccara (eds), New Development in Productivity Measurement and Analysis. Chicago: University of Chicago Press: pp. 419-54.

Griliches, Z. (1992). 'The search for R\&D spillovers'. Scandinavian Journal of Economics 94(supplement): 29-47.

Griliches, Z. (1994). 'Productivity, R\&D and the data constraint'. American Economic Review 84(1): 1-23.

Government of Pakistan (various Issues), Pakistan Economic Survey, Finance Ministry

Grossman, G. M. and Helpman, E. (1991). Innovation and Growth in the Global Economy. Cambridge MA: MIT Press.

Haddad, M. (1993). 'How trade liberalization affected productivity in Morocco'. Policy Research Working Paper 1096. Washington DC: World Bank.

Pasha, H.A., Aynul Hasan, and others 1996, Integrated Social-Sector Macroeconometric Model for Pakistan, Pakistan. Development Review, 35(4) 1996. PP 567-79

Hafiz, A. Pasha., Aisha, Ghaus-Pasha. and Kalim Hyder. (2002). "The Slowing Down of the Growth of Total Factor Productivity in Pakistan,” Social Policy and Development Centre, Research Report Number 44.

Harrison, A. E. (1994). 'Productivity, imperfect competition and trade reform: Theory and evidence’. Journal of International Economics 36: 53-73.

Harrison, A. E. (1996). 'Openness and growth: A time-series, cross-country analysis for developing countries’. Journal of Development Economics 48: 419-47.

Hercowitz, Z., Lavi, Y., and Melnick, R. (1999). 'The impact of macroeconomic factors on productivity in Israel, 1960-96’. Bank of Israel Economic Review 72: 103-124.

Kanamori, H 1972. “What Accounts for Japan's High rate of Growth?”, Review of Income and Wealth, 18(2), pp 155-71.

Khan, Safdar Ullah. (2006). "Macro Determinants of Total Factor Productivity in Pakistan,” State Bank of Pakistan, Working Paper Number 10.

Kim, E. (2000). 'Trade liberalization and productivity growth in Korean manufacturing industries: Price protection, market power and scale efficiency'. Journal of Development Economics 62: 55-83. 
Kim, K. W. (1994). 'Trade and industrialization policies in Korea: An overview', in G. K. Helleiner (ed.), Trade Policy and Industrialization in Turbulent Times. London and New York: Routledge, for UNU-WIDER.

Krugman, Paul. 1994 “The Myth of Asia’s Miracle”, Foreign Affairs, 73(6), pp 62.

Miller, S. M. and Upadhyay, M. P. (2000). 'The effects of openness, trade orientation, and human capital on total factor productivity'. Journal of Development Economics 63: 399-423.

Mohammad Sabir and Qazi Masood Ahmed. (2003). "Macroeconomic Reforms and Total Factor Productivity Growth in Pakistan: An Empirical Analysis,” Social Policy and Development Centre, Conference Paper No.55

Ramsey, F. P. (1928). ‘A mathematical theory of saving'. Economic Journal 38: 543- 59.

Romer, P. M. (1990). 'Endogenous technological change'. Journal of Political Economy 98(5): 71-102.

Romer, P. M. (1992). 'Two strategies for economic development: using ideas and producing ideas'. World Bank Annual Conference on Economic Development. Washington DC: World Bank.

Sachs, F. and Warner, A. (1995). 'Economic reform and the process of global integation’. Brookings Papers on Economic Activity 1995(1): 1-118.

Samuelson, P. A. (1958). 'An exact consumption-loan model of interest with or without the social contrivance of money’. Journal of Political Economy 66: 467-82.

Solow, R. M. (1956). 'A contribution to the theory of economic growth'. Quarterly Journal of Economics 70: 65-94.

Solow, R. M. (1957). 'Technical change and the aggregate production function'. The Review of Economics and Statistics 39: 312-20.

Wizarat, S. 1981 “Technological Change in Pakistan's Agriculture”, Pakistan. Development Review, 20(4), 1981, pp 427-45.

Yanrui Wa (1995) "Productivity Growth, Technological Progress and Technical Efficiency change in China: A Three-sector Analysis" Journal of Comparative Economics, 21, 207-229. 